\title{
THE POTENTIAL AND IMPLEMENTATION OF AGRICULTURAL ZAKAT IN AKEGURACI VILLAGE, CENTRAL OBA SUB-DISTRICT, THE CITY OF TIDORE ISLANDS
}

\author{
Nursinita Killian \\ Faculty of Sharia and Islamic Economic, Institut Agama Islam Negeri Ternate, \\ Maluku Utara, Indonesia, Jl. Lumba-lumba Kelurahan Dufa-dufa, Kota Ternate, \\ Maluku Utara, 97727 \\ E-mail: nursinita@iain-ternate.ac.id
}

\section{Nur Azizah Rahman}

Faculty of Sharia and Islamic Economic, Institut Agama Islam Negeri Ternate, Maluku Utara, Indonesia, Jl. Lumba-lumba Kelurahan Dufa-dufa, Kota Ternate,

Maluku Utara, 97727

E-mail: azizahrahman@iain-ternate.ac.id

\begin{abstract}
This article discusses the potential and implementation of agricultural zakat in Akeguraci village. This research aims to study the level of understanding and knowledge of the Akeguraci village farmers in the obligation of paying for zakat, especially agricultural zakat. The method used in this research is a qualitative descriptive analysis based on field research, in the form of direct observation and interviews. The result of this research indicated that the calculation and payment of the zakat of the Akeguraci village community were not following the provisions of Islamic sharia. This problem can be seen from the traditional management of zakat and the minimum level of awareness of farmers in issuing zakat so that their distribution could not be productive and on target. Public understanding reveals about zakat that must be issued is only zakat fitrah and zakat maal. While agricultural zakat has never been issued in any form. Zakat is given just as much as possible, without going through the calculation of agricultural products either by irrigation systems or purchasing water and in mobilizing workers to work to irrigate the fields
\end{abstract}

Keywords: Potential; Implementation; Agricultural Zakat

How to Cite: Killian, N., \& Rahman, N. A. (2020). The Potential and Implementation of Agricultural Zakat in Akeguraci Village, Central Oba Sub-District, the City of Tidore Islands. Jurnal Ilmiah Al-Syir'ah, 18(1), 63-76.

Permalink/DOI: http://dx.doi.org/10.30984/jis.v18i1.1083

Copyright (C) 2020, Jurnal Ilmiah Al-Syir'ah 


\section{Jurnal Ilmiah Al-Syir'ah Vol. 18, No. 1 (2020): 63-76 \\ Website: http://journal.iain-manado.ac.id/index.php/JIS ISSN 2528-0368 (online) ISSN 1693-4202 (print)}

\section{INTRODUCTION}

According to Islamic law, zakat is a certain portion of the property that has reached nisab which is paid by a Muslim by transferring ownership to those who are entitled to receive it (Qardawi, Harun, Hafidhuddin, \& Hassanuddin., 2006). Zakat is also one of the pillars of Islam and is propagated to the people of the Prophet Muhammad in Mecca that was still absolute, without limitation on the type and amount of assets as a form of kindness, self-esteem, and generosity of a Muslim (Thonthowi, 2001). After Rasulullah saw migrated to Medina in the 2nd year of Hijriyah, the provisions regarding the type and amount of assets regulated by detailed rules (az-zuhaily, nd).

Zakat is categorized as worship such as prayer, hajj, and fasting, which has been arranged in detail based on al-Qur'an and As-Sunnah but at the same time, it is also social zakat and humanity that can develop by the development of humanity. If zakat is managed properly, it can provide benefits in improving the people's economy. One type of zakat which is very potential in Indonesia is agricultural zakat. Determining muzakki from zakat in agriculture is very easy and a lot, because Indonesia is an agricultural country and the average income of Indonesia people comes from agricultural products and even the income of the middle to lower economic community (Hadad, 2017).

Research on agricultural zakat, especially in Akeguraci Village, Oba Tengah Subdistrict, Tidore Islands, is expected to contribute to understanding the people of Akeguraci Village as a form of implementing the obligation to issue zakat in Islam so that agricultural zakat can be applied by Akeguraci villagers who have never issued zakat on agricultural products even though their agricultural products has exceeded nisab.

Research on zakat in agriculture, previously there have been books and scientific works compiled to discuss zakat in terms of various aspects, as follows:

First, Abdul Ghofur Anshori (2006) described and discussed the management and distribution of zakat in each country varies with the times. In Indonesia through Law Number 38 of 1999, Article 6 paragraph 1 explains that: "zakat management is carried out by amil zakat agency established by the government". Therefore, the management of zakat in Akeguraci village by the amil zakat agency of Akeguraci Village requires direct control and good socialization of zakat management by Amil Zakat National Agency of the city of Tidore Islands thus zakat can be managed optimally.

Second, Yusuf al-Qardhawi (2006) explained the contextuality of shari'ah zakat that is a must and is non-negotiable. Yusuf al-Qardhawi divided zakat categories into 9 parts: 1) zakat of livestock, 2) zakat of gold and silver which also includes money, 3) zakat of commercial wealth, 4) zakat of agricultural products, 5) zakat of honey and animal production, 6 ) zakat on mining and marine products, 7) zakat on investment in factories, buildings, and others, 8) zakat on trade in

Potential and Implementation of Agricultural Zakat in Akeguraci Village, Oba Tengah District, Tidore Kepulauan City. 


\section{Jurnal Ilmiah Al-Syir'ah Vol. 18, No. 1 (2020): 63-76 \\ Website: http://journal.iain-manado.ac.id/index.php/JIS \\ ISSN 2528-0368 (online) ISSN 1693-4202 (print)}

services and professions, 9) zakat on shares and bonds. Akeguraci village has great potential in agriculture, so research on agricultural zakat in Akeguraci village is needed in terms of zakat management in agriculture.

Third, Ainiah (2017) stated that the calculation model of nisab zakat for agriculture in Kuta Makmur District was directly calculated with rice approximately $1,080 \mathrm{~kg}-1,260 \mathrm{~kg}$. Haul in agricultural zakat in Kuta Makmur District is used if the first crops do not reach nisab then it will be combined with other crops in the same year. However, if it reaches nisab, zakat is immediately issued without waiting for a year. The management of agricultural zakat in Kuta Makmur Subdistrict has been carried out well, hence, it is expected that Akeguraci Village can imitate the management and implementation of agricultural zakat.

Fourth, Sulhani Hermawan (2014) stated that Muslim farmers in Pucangan Village try to implement Islamic teachings by the development of understanding that they get along with the development of Islam in Pucangan. Zakat is understood as an obligation fulfilled at the end of Ramadan in the mosque where they live. But agricultural zakat has not occurred in Pucangan Village. The fact is by research conducted by Sulhani, it can be said that the implementation of agricultural zakat is almost the same as what happened in Akeguraci Village which has not become a reality yet.

Fifth, Rina and Suhada (2017) stated that the scholars agreed that agricultural zakat especially rice, is mandatory. But they differed on the number of rice must be issued. Some think if the rice has reached 100 belik, it must be issued for zakat but some think 85 belik must be issued. Agricultural zakat is not only required on rice but also on grains and fruits that have weighable, permanent, and dry that are of concern to humans when growing on their land. Therefore, the coconut crop which is the result of agriculture in Akeguraci Village is obligatory for agricultural zakat.

Sixth, Suhadi (2014) stated that the Indonesian government as ulil amri needs to provide implementation guidelines and detailed technical instructions related to agricultural zakat because the zakat law has not been clearly and explicitly stipulated on rice zakat although it can be argued, however, it will be stronger if the regulation is recorded. Likewise, with another agricultural zakat, it is not only rice but all plants as well categorized as obligatory should have their guidelines, therefore the agricultural zakat can be implemented by all Muslims.

Seventh, Budi al-Ashad (2016) stated that the method of calculating zakat for agricultural products carried out by the Sumberjokidul Village community, there are the provisions of fiqh and some are not following the provisions of fiqh, the gross crops calculation is reduced by operational costs. While nisab of farmers in Sumberjokidul Village used the estimate to become the provisions for nisab used that was $10 \%$. The implementation of zakat in Sumberjo Kidul-Bojonegoro Village, although not entirely following the provisions of fiqh, has already been

Potential and Implementation of Agricultural Zakat in Akeguraci Village, Oba Tengah District, Tidore Kepulauan City. 


\section{Jurnal Ilmiah Al-Syir'ah Vol. 18, No. 1 (2020): 63-76 \\ Website: http://journal.iain-manado.ac.id/index.php/JIS \\ ISSN 2528-0368 (online) ISSN 1693-4202 (print)}

implemented, compared to the implementation of agricultural zakat in Akeguraci Village which has not been carried out due to the lack of knowledge about zakat.

Agricultural zakat is unique zakat and is different from some other categories of zakat, agricultural zakat is issued when harvesting without waiting for a year (haul) and nisab is relatively smaller than other zakat but the level of expenditure is greater than between $5 \%$ and $10 \%$. Agricultural zakat is the easiest and fastest zakat to fulfill, and harvesting habits are carried out at the same time as happened in Akeguraci Village, Oba Tengah District, Tidore Islands.

Akeguraci Village is located on Trans Halmahera Sofifi-Weda road, Oba Tengah Sub-District, Tidore Islands, North Maluku Province. Geographically the location of Tidore Islands is at the astronomical boundary: $0^{\circ}-20^{\circ} \mathrm{NL}$ to $0^{\circ}-50^{\circ}$ SL, $127^{\circ} 10^{\prime}-127^{\circ} 45^{\prime}$ East Longitude. Judging from the geographical location, the City of Tidore Islands is located almost in the middle of the North Maluku Province so it has almost equal accessibility throughout the province (Kepulauan, 2016). In Oba Utara Subdistrict, Tidore Islands, there is a Provincial Government Center which is in Sofifi Sub-District, most of the facilities and infrastructure of the Provincial Government offices are directed towards development in the area.

The city which is near Ternate on Ternate Island also facilitates accessibility from Tidore to Ternate in which there are some service centers, trade centers, and adequate ports and airports for services on a national scale. From two cities in North Maluku Province, Tidore Islands is the largest city, but the population is not too large in its area. With the population that is not too large at this time, it allows the application of accelerated development in the City of Tidore Islands so that the concentration of the population has increased significantly (Kepulauan, 2016).

In 2008, from Regional Regulation Number 13,14,15, and 16 of 2007 and Regional Regulation Number 1 of 2008, administratively, Tidore Islands has developed into 8 districts consisting of 72 villages. Oba district was expanded into Oba Subdistrict and South Oba Subdistrict, while North Oba Subdistrict was expanded into Central Oba Subdistrict and North Oba Subdistrict. And finally, the Tidore sub-district was divided into Tidore sub-district and East Tidore sub-district. And until 2014, there were several villages in the City of Tidore Islands which were divided into 8 districts with 40 sub-districts and 49 villages (Kepulauan, 2016).

Akeguraci Village is one of the villages included in Tidore Islands government area, located in Central Oba Subdistrict, Tidore Islands, Akeguraci Village has a population of 603 people with 330 men and 273 women according to the profile data of Akeguraci village. Most of Akeguraci village residents work as farmers, the income is mostly from agricultural products. The total area of the village of Akeguraci as a whole, with an area of $1000 \mathrm{~m} \times 500 \mathrm{~m}$ of residential areas and an area of 36 hectares of agricultural area.

The village of Akeguraci is adjacent to the south with the village of Fanaha, the north is bordered by Akesai village, the west is bordered by the sea/beach, and

Potential and Implementation of Agricultural Zakat in Akeguraci Village, Oba Tengah District, Tidore Kepulauan City. 


\section{Jurnal Ilmiah Al-Syir'ah Vol. 18, No. 1 (2020): 63-76 \\ Website: http://journal.iain-manado.ac.id/index.php/JIS ISSN 2528-0368 (online) ISSN 1693-4202 (print)}

the east is bordered by a community plantation. To identify the boundaries of each village easier, each road connecting Akeguraci village to the neighboring village is given a gate that says village boundary. The village boundaries and gates in each village as a preventive measure against the security of the village and residents from communities outside the village (Kepulauan, 2016).

Central Oba Subdistrict, Tidore City consists of 13 villages, one of them is Akeguraci village. Historically in the Central Oba sub-district, there are several tribes, including Tobaru, Sanger, Tidore, and Makian tribes. Specifically, in Akeguraci village, most of the people are from the Makian tribe. The people of Akeguraci village are $100 \%$ Muslim and devoutly practicing religion properly. The atmosphere of religious life is more prominent and even has become an integral part of their daily lives. The social life of the village community when performing a celebration both personally and public celebration always help each other, hence in many social problems can be solved together.

In the Akeguraci village, in the cultural and daily interactions, they use the Makian language as the language of internal communication and externally use Indonesian even though it is often mixed with the Makian language. Because the majority of Akeguraci village tribes are Makian tribes so that language remains a symbol or its trademark. Even though most of the villagers of Akeguraci are from the Makian tribe, chronologically the name of this village does not use Makian language but rather the Tidore language, because Akeguraci village belongs to the Tidore Islands government area. The educational background of the community in Akeguraci Village is mostly only up to senior high school level, which is only a small portion of tertiary education.

Akeguraci Village, Central Oba Subdistrict, Tidore Islands, where most of the residents work as farmers, it is seen from agricultural land owned by residents reaching 36 hectares (Interview with Jufri, Secretary of Akeguraci Village, $17^{\text {th }}$ June 2019). Therefore, the potential for agricultural products in Akeguraci village at each harvest reaches 5-6 tons in once, but the results of this study indicate that every agricultural or plantation product obtained by Muslim farmers in of Akeguraci village has not been issued to agricultural zakat. Zakat that should be issued by the Akeguraci village community is zakat for agriculture because the agricultural products at harvest have reached the zakat nisab for agriculture. Research on zakat in agriculture is needed in improving a more prosperous village through the management of agricultural zakat. Besides, this research is expected to give understanding about the obligation of agricultural zakat to the Akugeraci Village community, Central Oba Subdistrict, the city of Tidore Islands.

\section{RESEARCH METHODS}

This research is a descriptive qualitative research based on field research, with a qualitative descriptive approach and qualitative analysis techniques in the form of observations and interviews. This research produces written or oral data from people or subjects observed through research procedures directly in the field.

Potential and Implementation of Agricultural Zakat in Akeguraci Village, Oba Tengah District, Tidore Kepulauan City. 


\section{Jurnal Ilmiah Al-Syir'ah Vol. 18, No. 1 (2020): 63-76 \\ Website: http://journal.iain-manado.ac.id/index.php/JIS ISSN 2528-0368 (online) ISSN 1693-4202 (print)}

This means that researchers analyze and describe research objectively and in detail. This research is expected to provide a detailed, systematic, and comprehensive picture of all matters relating to agricultural zakat, especially on the potential and implementation of agricultural zakat in Akeguraci Village, Central Oba SubDistrict, Tidore Islands.

The approach used in this research is Juridical Approach and Normative Approach. A juridical approach is an approach by looking at some provisions of the Islamic law that have been applied in the form of legislation, or government regulations that have relevance to this research without leaving the values growing and developing in society. The normative approach is the approach to see and hold fast to the norms and principles applying in Islamic law.

The source of primary data consisted of 25 respondents, they are 1 person from Amil Zakat National Agency of Tidore Islands, a chairman of the committee of amil zakat agency of Akeguraci village, a religious leader, an Akeguraci village headman, Akeguraci village secretary, and 15 Akeguraci villagers. Besides, secondary data sources in this study are in the form of text, books, and other documents used by researchers to strengthen the findings in the field.

The data collection techniques used observation and interviews. The researcher observed and interviewed to perfect the data that researchers find in the field. Data processing is by using data breakdown to provide the results of observations and easier for researchers to find it if at any time needed. The data analysis model used in this study is an interactive model developed by Miles and Huberman that starts with data collection, data presentation, and conclusion (Sugiyono, 2012). To analyze qualitative data from observations and interviews, the researchers conducted a field note, sorting out, classifying, making summaries, and ending with giving meaning to the data.

\section{RESULTS AND DISCUSSION}

\section{The Concept of Agricultural Zakat According to Islamic Law}

Zakat is derived from the word zaka-yazku - zakah which means blessing, growing, clean, good, and increasing (Ikhraj \& et al, 2011). Agricultural zakat is the process of implementing the compulsory rights of agricultural assets/ products (all that is grown using seeds whose yield can be eaten by humans and animals) (Al-Qarḍāwi, 2006). It can be said that agricultural zakat is one type of zakat mal. The objects include the crops or plants with economic value. Therefore, there is the obligation of zakat on all types of plants that have economic value. This is in line with the words of the Prophet, which means: "Plants that are watered by the sky and springs or that absorb from nearby water have a tenth of zakat obligation, plants that are by watering it, then there is a twentieth of zakat obligation". (Bukhari HR) (al-Ja'fi, 2001).

Potential and Implementation of Agricultural Zakat in Akeguraci Village, Oba Tengah District, Tidore Kepulauan City. 


\section{Jurnal Ilmiah Al-Syir'ah Vol. 18, No. 1 (2020): 63-76 \\ Website: http://journal.iain-manado.ac.id/index.php/JIS \\ ISSN 2528-0368 (online) ISSN 1693-4202 (print)}

The obligation to issue agricultural zakat is also specifically mentioned in several verses of al-Qur'an including in Surah Al-An'am: 141 and Surah AlBaqarah: 267. The Messenger of Allah said, which means:

"It has been narrated from Ibn Abbas that when the Prophet sent Mu'az Ibn Jabal Ra. to become a qadhi in Yemen. He said: "... If this they have obeyed, say that Allah Ta'ala has obliged zakat on their property, which is collected from the rich and given to the poor among them. If they fulfill this, you should avoid their valuable possessions, and fear the prayers of those who are persecuted because there is no barrier between them with Allah. (Bukhari HR) (al-Ja'fi, 2001).

According to Imam Abu Hanifah, agricultural zakat must be removed from all types of plants that grow on earth, both in small or large amounts, except for firewood, grasses, bamboo parsi, tree stems and all plants that grow accidentally. But if the land is deliberately used as a place for the growth of bamboo, trees, and grass, irrigated regularly and forbidden by other people to touch it, then it is obligatory to pay zakat (al-Qarḍāwi, 2006).

Imam Malik believes that agricultural zakat is required on 20 kinds of plants. Some kinds of grains, such as soybeans, peanuts, and short beans, wheat, taro, corn, tobacco, rice, olives, and red radishes. The types of fruits that must be issued for zakat are dates, grapes, and olives.

According to Imam Syafi'I, agricultural zakat is only devoted to satiating foods, from fruits, such as dates and dried grapes, while from the grains are wheat, rice, and all filling foods such as soybeans and corn. Imam Hambali believes that the zakat of agriculture must be removed from any filling, can be measured, and stored grain, such as corn, soybeans, short beans, tobacco, and rice (al-Qarḍāwi, 2006).

\section{The Model of Calculation of Agricultural Zakat According to Islamic Law}

Nisab zakat is calculated from harvests that have been dried and cleaned from their skins or equivalent (As-Sābiq, 1999). For yields that cannot be weighed, the ratio is 5 ausuq. Plants such as rice that are stored without being separated from the skin may be issued for zakat and counted the worth of rice nisab or double the rice scales (Quddāmah, 1968).

There are differences in Ulama in determining the size of wasq. One wasq is equivalent to 60 sha. According to Hanafiah, 1 wasq is $195 \mathrm{~kg}$, so that 5 ausuq becomes $875 \mathrm{~kg}$. While Jumhur Ulama determines 1 wasq of $122.4 \mathrm{~kg}$ so that 5 ausuq is the size of $610 \mathrm{~kg}$ (Jum'ah, 2009). In the calculation of the Amil Zakat National Agency, one sha is $2.176 \mathrm{~kg}$, then 5 ausuq is $5 \times 60 \times 2.176=652.8 \mathrm{~kg}$ of rice ("Zakat Pertanian," n.d.). This calculation model is in line with Imam Yusuf al-Qardhawi's calculation, but this calculation is revised and becomes $647 \mathrm{~kg}$ of rice (al-Qarḍāwi, 2006). 
Jurnal Ilmiah Al-Syir'ah Vol. 18, No. 1 (2020): 63-76

Website: http://journal.iain-manado.ac.id/index.php/JIS

ISSN 2528-0368 (online) ISSN 1693-4202 (print)

If the yield has exceeded 1 ton $(1000 \mathrm{~kg})$, it is subject to the obligation of zakat. For example: if a farmer's harvest is 10 tons $=10,000 \mathrm{~kg}$, then $10,000 \times 5 \%$ $=500 \mathrm{~kg}$. If it is converted to rupiah and the rice price is Rp. 10,000, - then 10,000 kg x Rp. 10,000, - = Rp. 100,000,000. Rp. 100,000,000 x 5\% = Rp. 5,000,000. The zakat is $500 \mathrm{~kg}$ of rice or Rp. 5,000,000. Zakat issued can be in the form of harvest or cash.

\section{The Potential of Agricultural Zakat in Akeguraci Village, Central Oba District, Tidore Islands}

Agricultural zakat is prescribed to plants that can grow and develop. This zakat is divided into two, they are fruits and seeds. Both are not required to be issued for zakat unless they meet several criteria: being a staple food for humans in their normal conditions, allowing it to be stored and not easily damaged/decomposed, can be planted by humans, and reach nisab from their crops.

Akeguraci village from the area of agricultural land owned by the community, both agricultural land that has been cultivated and has obtained results or that has not been cultivated is 36 hectares of agricultural land (Interview with Jufri, Secretary of Akeguraci Village, $17^{\text {th }}$ June 2019). Akeguraci village with most of its people work as farmers with the main income coming from coconuts turned into copra. Also, farmers grow cocoa, cloves, and nutmeg. Most of the agricultural land owned by residents is planted with coconut and the rest is planted with cocoa, cloves, and nutmeg. The data as follows:

\section{Table 1. Data on Agricultural Products of Muslim Farmers in Akeguraci Village}

\begin{tabular}{ccc}
\hline Type of agriculture & Number of trees & Production (kg / ton) \\
\hline Nutmeg & 2,224 & 129.4 \\
Cocoa & 145 & 26 \\
Clove & 149 & 37.25 \\
Coconut & 1,815 & 23.35 \\
\hline
\end{tabular}

Source: Akeguraci Village Profile Data for 2019

Table 1 shows that the crops of Muslim farmers in Akeguraci Village, based on the profile data of the Akeguraci Village in 2019 consisted of several types of plants; nutmeg plants with the total number of trees owned by Akeguraci Village farmers as a whole are 2,224 trees with the number of harvests produced $129.4 \mathrm{~kg}$ once a year per householder, cacao plants with a total of 145 trees with the harvest of $26 \mathrm{~kg}$ per year per householder, clove plants with a total of 149 trees with the

Potential and Implementation of Agricultural Zakat in Akeguraci Village, Oba Tengah District, Tidore Kepulauan City. 


\section{Jurnal Ilmiah Al-Syir'ah Vol. 18, No. 1 (2020): 63-76 \\ Website: http://journal.iain-manado.ac.id/index.php/JIS ISSN 2528-0368 (online) ISSN 1693-4202 (print)}

harvest of average $37.25 \mathrm{~kg}$ once a year per householder, and coconut trees with a total of 1,815 trees with a quarterly harvest of an average of 23.35 tons per year calculated from the total coconut plants owned by farmers.

There are several reasons why farmers in Akeguraci village prefer coconut as its mainstay crop, because coconut plants are easier and practically to be planted, less trouble compared to other plants, the expenditure of maintenance costs is relatively low, in terms of obtaining the results of growing coconuts more profitable than other plants, even though processing it into copra is a waste of time and energy (Kubais Muhammad Interview, Akeguraci village farmer, $19^{\text {th }}$ June 2019).

Economically, coconut plants have relatively small capital expenditure but have doubled profits. In addition to harvesting coconuts 4-5 times a year, farmers can also produce 5-6 tons of coconut in one harvest, if the price of coconuts is stable according to standards, farmers can benefit around Rp. 4,000,000-5,000,000 per harvest. (Interview with Suhaim, Head of Akeguraci Village, August $1^{\text {st }}, 2019$ ).

The Akeguraci village community uses the land as the standard of wealth. Communities who own large tracts of land or agricultural land, including those who own property and who do not own agricultural land, are said to be poor and forced to work as day laborers or find other works. (Interview with Suhaim, Head of Akeguraci Village, August 1 $\left.{ }^{\text {st }}, 2019\right)$.

Farmers who own agricultural land even though only a half hectare, but if it is measured from agricultural yields obtained by the harvest, it can be categorized quite capable in terms of economics. In reality of socioeconomic life, agricultural land owned by Akeguraci villagers, even though only a half hectare is categorized as middle economy, can be seen from the simple life of the community thus it does not reach the category of the high economic class despite having extensive agricultural land. (Interview with Yasir Hi Syarif, Akeguraci village farmer, $19^{\text {th }}$ June 2019).

The Amil Zakat Agency of Akeguraci village in managing zakat, infaq, and sadaqah, has referred as a benchmark for the management of zakat including determining the muzakki and mustahiq, because the identity of muzakki and mustahiq in Akeguraci village has been identified through property or agricultural land owned (Jalal Interview, Chairman of the Amil Zakat Agency of Akeguraci village, July $13^{\text {th }}$, 2019).

Citizens who own agricultural land even though only a half hectare are classified as muzakki. Whereas community members who do not own property or agricultural land are categorized as poor people who are recipients of zakat (mustahiq). Also, there are several groups determined by the AZA of Akeguraci village as recipients of zakat each year, they are orphans, widows, and fisabilillah (Interview with Muksin, Deputy Chairman of the AZA of Akeguraci village, $13^{\text {th }}$ July 2019). 


\section{Jurnal Ilmiah Al-Syir'ah Vol. 18, No. 1 (2020): 63-76 \\ Website: http://journal.iain-manado.ac.id/index.php/JIS \\ ISSN 2528-0368 (online) ISSN 1693-4202 (print)}

The management of zakat starts from the existence of the zakat obligation as it is known in al-Qur'an surah at-Taubah verse 60. In Akeguraci village, the management of zakat began since ancient times, from the beginning of the first generation of migration to that place. Every Muslim must realize and know the zakat obligation because it is related to the pillars of Islam, such as zakat mal and zakat fitrah which are issued at the end of Ramadan. The procedure for issuing zakat fitrah and zakat mal in Akeguraci Village is the same as the procedure for issuing zakat in general, there are no specific customs in terms of zakat issued (Jalal Interview, Chairman of AZA, Akeguraci village, $13^{\text {th }}$ July 2019).

However, the obstacle in the management of zakat in Akeguraci village is that the management is still traditional and its distribution in a consumptive manner has not touched productive distribution. Due to the lack of understanding of the management of zakat and the formation of AZA which is only appointed directly at the end of Ramadan. AZA only workes in Ramadan hence the management of zakat only stopped until the receipt and distribution of zakat mal and zakat fitrah in Ramadan. After Ramadhan, AZA no longer functions as a manager of the zakat. Because what is known is that there is the only zakat mal and zakat fitrah whereas there are also other zakat obligations, one of them is agricultural zakat (Interview with Jufri, Secretary of Akeguraci Village, $17^{\text {th }}$ June 2019).

Akeguraci village is one of the villages that has potential in agriculture because most of the village community's profession is as farmers with the main yield of coconut. The management of agricultural products brings abundant benefits. If the results of community agriculture can be managed properly through the management of agricultural zakat, it will bring maximum results for the benefit of the poor in particular and the interests of rural communities in general.

\section{The Implementation of Agricultural Zakat According to Community's View in Akeguraci Village, Central Oba Subdistrict, Tidore Islands}

The obligation of zakat has two main objectives, first, the issue of zakat is the command of Allah, then a Muslim who has fulfilled it means directly carrying out the command of Allah SWT to clean his soul and property. Secondly, zakat is the command of Allah as social worship that is related to human needs, so every Muslim who issues it means directly alleviating the suffering of others especially those who are poor and need help.

The various types of assets that must be issued for zakat is adjusted to the situation and conditions at the time of the Prophet. It can be seen from the verses that underlie the obligation to issue zakat is still general, thus it shows the flexibility of Islamic law that can develop by the times, and the ijtihad to expand the reach of zakat objects in modern conditions. This is certainly inseparable from the legal illat already mentioned in the nash of al-Qur'an and al-Hadith.

The existence of amil in the management of zakat must also be a concern, based on Allah's command (QS9: 60) which mentions them with the words

Potential and Implementation of Agricultural Zakat in Akeguraci Village, Oba Tengah District, Tidore Kepulauan City. 


\section{Jurnal Ilmiah Al-Syir'ah Vol. 18, No. 1 (2020): 63-76 \\ Website: http://journal.iain-manado.ac.id/index.php/JIS \\ ISSN 2528-0368 (online) ISSN 1693-4202 (print)}

"administrators of zakat". Amil obtained one part of zakat from the eight parts as mentioned in the verse above. Qardhawi when interpreting at-Taubah:60 stated that amil are those who are assigned by the imam/government to take, write, count, and record the alms taken from muzakki to be given to those who deserve to receive them (al-Qarḍāwi, 2006).

According to Wahbah, the portion given to the committee was categorized as wages for work, not based on status but related to professionalism. Amil's professionalism in managing zakat is an important part of a zakat institution so that the recruitment is based on certain criteria: having knowledge and understanding of zakat, being trustworthy, honest, fair and faithful, and able to work full time in managing zakat (az-Zuhaily, n.d).

Based on Wahbah's opinion above, the zakat collection institution at the village level that was specifically formed to handle zakat is required to have certain requirements, therefore in the case of zakat management, it will not raise suspicions in the community. Requirements that must be fulfilled as zakat managers, for example, people who understand how to manage zakat according to Islamic law, understand how to distribute zakat to needed groups, use of zakat received to a better village economy, and is required by people who are trustworthy and responsible in carrying out their duties.

The institutionalization of zakat both in the form of agencies and institutions with a professional and transparent management system is one of the requirements for the realization of zakat for social change and social justice. It is impossible to develop zakat as a tool of change if it only relies on individual efforts to overcome poverty by giving zakat directly to the poor without going through an institution.

In traditional societies, the management of zakat is also still based on traditional and has a very simple structure, but has a strong commitment to a value order from the principles of the community itself. Islam in traditional societies is still considered original and textualist. These traditional societies are vulnerable to change, their survival is very high and a strong work ethic, but not organized, so they are seen working hard but not getting maximum results.

Regarding zakat on agricultural products, some literature mention not only limited to grapes and dates but also orchids, rambutans, mangoes, durian, salak, papaya, and any agricultural products that have economic value and earn a lot of money or even enrich must issue for zakat.

The people of Akeguraci village, Central Oba Subdistrict, Tidore Islands, are mostly dependent on agriculture. Agricultural products of Akeguraci village consist of coconut, nutmeg, cloves, cassava, peanuts, and cocoa. But the dominant agricultural product is coconut. Farmers are the profession of most Akeguraci villagers, although the main focus of the economy is agriculture, the Akeguraci villagers not only prioritize their income from agricultural products, but there is also from trading, raising livestock, fishing by looking for seafood and others.

Potential and Implementation of Agricultural Zakat in Akeguraci Village, Oba Tengah District, Tidore Kepulauan City. 


\section{Jurnal Ilmiah Al-Syir'ah Vol. 18, No. 1 (2020): 63-76 \\ Website: http://journal.iain-manado.ac.id/index.php/JIS \\ ISSN 2528-0368 (online) ISSN 1693-4202 (print)}

After seeing, observing and researching the process of managing zakat and the implementation of zakat for agricultural products in Akeguraci village, researchers can explain that the problem in the implementation of agricultural zakat in this village is Akeguraci village farmers in paying zakat for their agricultural products, still using the traditional system of their belief. Most Akeguraci village farmers think that zakat mal which is issued at the end of Ramadan is the same as agricultural zakat. Therefore, the zakat issued is just a little because of the lack of knowledge of agricultural zakat. The farmers do not know how to calculate the agricultural zakat based on Islamic shari'a that requires zakat for agricultural products if it has reached its nisab of agricultural zakat.

Akeguraci village community, both in calculating zakat and paying is still relatively dependent on the level of their awareness. For farmers who understand the provisions of zakat according to fiqh, they will certainly issue zakat on agricultural products. Therefore, socialization is needed to provide an understanding of the community about the obligation to issue zakat for agricultural products.

In addition to the constraints of the community's lack of understanding agricultural zakat, another obstacle is the absence of organizations or institutions handling zakat specifically in Akeguraci village. AZA which is only formed in Ramadan not only works and responsible in Ramadan but must also after Ramadan, as a permanent and legal institution for managing various types of zakat. Thus, the implementation of zakat especially agricultural zakat as an obligation can be implemented well.

AZA of Akeguraci village in the management and distribution of zakat fitrah and zakat mal is only limited to the distribution of zakat to mustahiq and religious facilities and infrastructure. Because there is no direct guidance or control from the Amil Zakat National Agency of the City of Tidore Islands in terms of performance and procedures for the management and distribution of zakat in detail.

\section{CONCLUSION}

The Akeguraci village when viewed from the total area of agricultural land owned by the community members, both agricultural land that has been cultivated and that has obtained results or that has not been cultivated, is 36 hectares. Most of Akeguraci villagers work as farmers with the main income coming from coconuts turning into copra. The harvesting of coconut trees can be 4-5 times a year, farmers can also produce 5-6 tons of coconut in one harvest, if the price of coconuts is stable according to standards, farmers can benefit around Rp. 4,000,000-5,000,000 per harvest. After seeing, observing and researching the process of managing zakat and the implementation of zakat for agricultural products in Akeguraci village, researchers can explain that the problem in the implementation of agricultural zakat in this village is Akeguraci village farmers in paying zakat for their agricultural products, still using the traditional system of their belief. Most Akeguraci village farmers think that zakat mal which is issued at the end of Ramadan is the same as

Potential and Implementation of Agricultural Zakat in Akeguraci Village, Oba Tengah District, Tidore Kepulauan City. 


\section{Jurnal Ilmiah Al-Syir'ah Vol. 18, No. 1 (2020): 63-76 \\ Website: http://journal.iain-manado.ac.id/index.php/JIS ISSN 2528-0368 (online) ISSN 1693-4202 (print)}

agricultural zakat. Therefore, the zakat issued is just a little because of the lack of knowledge of agricultural zakat. The farmers do not know how to calculate the agricultural zakat based on Islamic shari'a that requires zakat for agricultural products if it has reached its nisab of agricultural zakat. The zakat collected by the AZA of Akeguraci Village at the end of Ramadan is limited to the distribution of zakat to mustahiq and religious facilities and infrastructure. Thus, the results of zakat in the village of Akeguraci from year to year do not increase and there is no change in the management and zakat distribution.

\section{ACKNOWLEDGMENTS}

Furthermore, this research involves many parties who always assist researchers, so that researchers realize that all forms of contribution in completing this research are priceless. Therefore, without reducing respect for others, the researchers would like to express special thanks and appreciation to several parties who assisted in this research, including the Litapdimas Ministry of Religious Affairs of the Republic of Indonesia, which has provided research funding assistance to researchers so that the research is done; Rector of IAIN Ternate Dr. Samlan Ahmad, M.Pd, through the IAIN Ternate Research Institute and Community Service who has trusted researchers in conducting this research; Tidore Islands Government, The Ministry of Religious Affairs of the City of Tidore Islands, AZNA of the City of Tidore Islands and their staff who have given permission and opportunities for researchers to research the City of Tidore Islands; and the Head of Akeguraci Village Suhaim Hi. Saleh, Secretary of Akeguraci Village, Jufri, the staff of Akeguraci Village, and the entire community of Akeguraci Village who have provided the opportunity for researchers to conduct research, serve, provide information and data needed. Therefore, this research can be completed well.

\section{REFERENCES}

Ainiah. (2017). Model Perhitungan Zakat Pertanian (Studi di Kecamatan Kuta Makmur Aceh Utara). UIN Sumatera Utara.

Al-Ashad, B. (2016). Pengaruh Pembayaran Zakat Pertanian Terhadap Kesejahteraan Masyarakat Desa Sumberjo Kidul-Bojonegoro (Kajian Sosial Hukum Islam). Jurnal Penelitian Hukum Islam Syakhsiyyah Burhaniyah, 1(1), $57-78$.

Al-Ja'fi, M. I. I. A. 'Abdullāh al-B. (2001). Șaḥiḥ al-Bukhāri (Al-Jāmi' aṣ-Șaḥị̣ alMukhtașar min Umūr Rasūlillāh Ṣallallāh 'Alaihi wa Sallam wa Sunanih wa Ayyāmih). Dār Tūq an-Najāḥ.

Al-Qarḍāwi, Y. (2006). Fiqh az-Zakāh. Kairo: Maktabah Wahbah.

Anshori, A. G. (2006). Hukum dan Pemberdayaan Zakat; Upaya Sinergis Wajib Zakat dan Pajak di Indonesia. Yogyakarta: Pilar Media.

As-Sābiq, A.-S. (1999). Fiqh as-Sunnah. Kairo: Dār al-Fatḥ li al-I'lām al- ‘Arabiy.

Potential and Implementation of Agricultural Zakat in Akeguraci Village, Oba Tengah District, Tidore Kepulauan City.

Nursinita Killian, Nur Azizah Rahman 


\section{Jurnal Ilmiah Al-Syir'ah Vol. 18, No. 1 (2020): 63-76 \\ Website: http://journal.iain-manado.ac.id/index.php/JIS ISSN 2528-0368 (online) ISSN 1693-4202 (print)}

Hadad, Y. (2017). Dinamika Pengelolaan Zakat di Indonesia. Tangerang Selatan: Anugrah.

Hermawan, S. (2014). Pemahaman dan Pelaksanaan Zakat Pertanian Petani Muslim Di Desa Pucangan Kecamatan Kartasura Sukoharjo.

Ikhraj, A. A., \& Dkk. (2011). al-Mu 'jam al-Wasith. Kairo: al-Maktabah al-Syuruq al-Dauliyah.

Jum'ah, A. (2009). Al-Makāyil wa al-Mawāzin asy-Syar'iyyah. Kairo: Dār arRisālah.

Kepulauan, T. (2016). Rencana Program Investas Jangka Menengah (RPIJM) Tahun 2016-2020 Kota Tidore Kepulauan. Retrieved from http://profil_kota_tidore_kepulauan_ok.pdf

Qardawi, M. Y., Harun, S., Hafidhuddin, D., \& Hassanuddin. (2006). Hukum zakat: studi komparatif mengenai status dan filsafat zakat berdasarkan Quran dan hadis. Pustaka Litera Antarnusa.

Quddāmah, I. al-M. (1968). Al-Mugni. Kairo: Maktabah al-Qāhirah.

Rina, \& Suhada. (2017). Dakwah Ulama Tentang Zakat Pertanian di Kecamatan Anjir Pasar Kabupaten Barito Kuala. Retrieved April 30, 2019, from ResearchGate website: https://www.researchgate.net/publication/317430887_Dakwah_Ulama_Tenta ng_Zakat_Pertanian_Di_Kecamatan_Anjir_Pasar_Kabupaten_Barito_Kuala

Sugiyono. (2012). Metode Penelitian Kuantitatif, Kualitatif dan $R \& D$ (15th ed.). Bandung: CV. Alfabeta.

Suhadi. (2014). Telaah Ulang Kewajiban Zakat Padi dan Biaya Pertanian Sebagai Pengurang Zakat (Analisis Fatwa-fatwa di Media Sosial. Ziswaf, 1(2), 336378.

Thonthowi, M. S. (2001). Al-Fiqh al-Musayyar. Kairo: Dar as-Sa'dah.

Zakat Pertanian. (n.d.). Retrieved September 21, 2018, from Baznaz.go.id website: http://pusat.baznas.go.id/zakat-pertanian/

Zuhaili, W. (n.d.). Ushûl al-Fiqh al-Islâmî. Suriah: Dâr al-Fikr.

Potential and Implementation of Agricultural Zakat in Akeguraci Village, Oba Tengah District, Tidore Kepulauan City. 